\title{
HYDRATION-HARDENING PROPERTIES OF DIVALENT CATION-SUBSTITUTED $\alpha$-TRICALCIUM PHOSPHATE
}

\author{
Hideki Monma ${ }^{1}$, Yuji Hosoi ${ }^{2}$, Toshinori Okura ${ }^{2}$, Hironori Ogata ${ }^{1}$, \\ Yusuke Moriyoshi ${ }^{1}$ \\ (*Corresponding author:monma@cc.kogakuin.ac.jp)

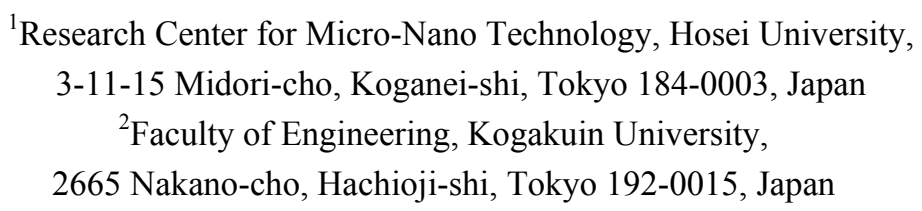

Keywords:Tricalcium phosphate, Hydroxyapatite, Hydration activity, Hydration-hardening,

Abstract: Divalent cation-substituted $\alpha$-phase tricalcium phosphates $\left(\alpha-\mathrm{Ca}_{3-\mathrm{x}} \mathrm{M}_{\mathrm{x}}\left(\mathrm{PO}_{4}\right)_{2}\right.$, where $\left.\mathrm{M}=\mathrm{Mg}, \mathrm{Zn}, \mathrm{Sr}, \mathrm{Ba}\right)$ were obtained by heating at $1500^{\circ} \mathrm{C}$ for $\mathrm{M}=\mathrm{Mg}(x=0.03), 1400^{\circ} \mathrm{C}$ for the others $(x=0.09)$, respectively. The resulting products were characterized by XRD, hydration reactivity and hydration-hardening strength. The hydration reactivity of these $\alpha$-phase phosphates was decreased by the substitutions, regardless of smaller or larger $\mathrm{M}$ in ion size than $\mathrm{Ca}$, i.e., the $\alpha$ phase was chemically stabilized.

(Received May 19, 2010; Accepted July 31, 2010)

\section{INTRODUCTION}

Tricalcium phosphate $\left(\mathrm{Ca}_{3}\left(\mathrm{PO}_{4}\right)_{2}\right.$, referred to as TCP) has two polymorphs named low temperature form $\beta$ and high temperature form $\alpha$. The transition temperature is $c a .1180^{\circ} \mathrm{C}$. Sintered $\beta$-TCP is applied to artificial bone substitute. Whereas powdery $\alpha$-TCP having a unique hydration-hardening property is a basic material for artificial bone cements. In the sintering of $\beta$-TCP, higher temperatures than the transition temperature were generally required. So, many studies on increasing the transition temperature have been done through the substitution of various kinds of cations for $\mathrm{Ca}^{2+}$. For instance, the substitutions of $\mathrm{Al}^{3+}$ and $\mathrm{Mg}^{2+}$ resulted in a remarkable chemical and structural stability of the $\beta$ structure, e.g., no transition into $\alpha$-TCP occurred even at $1300^{\circ} \mathrm{C}^{1,2)}$. Observed lattice contracts of the $\beta$ structure were discussed in relation to the differences in ion radius among $\mathrm{Al}^{3+}(0.057$ $\mathrm{nm}), \mathrm{Mg}^{2+}(0.072 \mathrm{~nm})$ and $\mathrm{Ca}^{2+}(0.100 \mathrm{~nm})$. On the other hand, $\alpha$-TCP is easily prepared by rapid cooling from temperatures above the transition temperature, however basic and crystal chemical studies such as studies on $\beta$-TCP have been a little. Motisuke et al. ${ }^{3)}$ prepared Si-doped $\alpha$-TCP with a $\mathrm{Si} /(\mathrm{P}+\mathrm{Si})$ mol\% of 2.5 below $1200^{\circ} \mathrm{C}$. Barnes et al. ${ }^{4)}$ reported that quenched products from $1500^{\circ} \mathrm{C}$ in the system TCP-Ca $\mathrm{CiO}_{4}$ hydrated to form a mixture of hydroxyapatite (HAp, stoichiometrically $\left.\mathrm{Ca}_{5}(\mathrm{OH})\left(\mathrm{PO}_{4}\right)_{3}\right)$, C-S-H gel and $\mathrm{Ca}(\mathrm{OH})_{2}$, however the hydration activities of quenched products were lower than that of pure $\alpha$-TCP. At present, controlling or increasing the hydration and hardening properties of $\alpha$-TCP has become of interest in the fields of biomaterials.

In the present work, the influence of the substitution of divalent cations for $\mathrm{Ca}^{2+}$ in $\alpha$-TCP on the hydration-hardening properties was investigated. The cations were $\mathrm{Mg}^{2+}$ $(0.072 \mathrm{~nm}), \mathrm{Zn}^{2+}(0.075 \mathrm{~nm}), \mathrm{Sr}^{2+}(0.116 \mathrm{~nm})$ and $\mathrm{Ba}^{2+}(0.136 \mathrm{~nm})$ which are smaller or larger ions in size than $\mathrm{Ca}^{2+}$. 


\section{EXPERIMENTAL}

Stoichiometric mixtures with 1.50 in $(\mathrm{Ca}+\mathrm{M}) / \mathrm{P}$ molar ratio $(\mathrm{M}=\mathrm{Ca}, \mathrm{Mg}, \mathrm{Zn}, \mathrm{Sr}$, $\mathrm{Ba})$ were prepared using reagent grades of $\mathrm{CaHPO}_{4} \cdot 2 \mathrm{H}_{2} \mathrm{O}, \mathrm{CaCO}_{3}, \mathrm{MgO}, \mathrm{ZnO}, \mathrm{SrO}$ and $\mathrm{BaO}$. Mixing molar ratios in $\mathrm{M} /(\mathrm{Ca}+\mathrm{M})$ were 0.00 for $\mathrm{Ca}, 0.01$ for $\mathrm{Mg}$ and 0.03 for the others. The mixtures were milled for $3 \mathrm{~h}$ using an automatic alumina mortar. Thus obtained mixtures were heated two times at $1000^{\circ} \mathrm{C}$ for $3 \mathrm{~h}$, then heated for $3 \mathrm{~h}$ at $1300^{\circ} \mathrm{C}$ for pure $\alpha-\mathrm{TCP}(\mathrm{M}=\mathrm{Ca})$, at $1500^{\circ} \mathrm{C}$ for $\mathrm{M}=\mathrm{Mg}$, at $1400^{\circ} \mathrm{C}$ for $\mathrm{M}=\mathrm{Zn}, \mathrm{Sr}$ and $\mathrm{Ba}$, and then cooled rapidly to room temperature. The resulting products written as $\mathrm{Ca}_{2.97} \mathrm{Mg}_{0.03}$ $\left(\mathrm{PO}_{4}\right)_{2}$ and $\left.\mathrm{Ca}_{2.91} \mathrm{M}_{0.09}\left(\mathrm{PO}_{4}\right)_{2}\right) ; \mathrm{M}=\mathrm{Zn}, \mathrm{Sr}, \mathrm{Ba}$ were confirmed to have the $\alpha$ single phase by XRD (MAC SCIENCE, M03X-HF, CuKa-radiation, $40 \mathrm{kv}-15 \mathrm{~mA}$, slits:1- 1-0.15, scan speed: $2 \% \mathrm{~min}$ ). The hydration reactivity was evaluated by qualitative observation of appeared XRD peaks of HAp and of hardening or non-hardening of the powder sediment after the hydration run (1.0 g powder sample / 50 $\mathrm{ml} \mathrm{H}_{2} \mathrm{O}$, at $80^{\circ} \mathrm{C}$ for $1 \mathrm{~h}$, without stirring). After the preliminary observation with XRD and SEM (HITACHI, Model S-2380N)) on hydration-hardening, prepared $\alpha$-phase TCP powders were ground and passed through 150-mesh sieve. Then slurries with $\mathrm{H}_{2} \mathrm{O}$ at Powder/Liquid=1.67 $\mathrm{g} / \mathrm{g}$ were poured into a brass mold with $10 \times 10 \times 80 \mathrm{~mm}$, wrapped with a commercial plastic thin film, then warmed at $80^{\circ} \mathrm{C}$ for $3 \mathrm{~h}$. Thus obtained products were demolded, dried at $40^{\circ} \mathrm{C}$ for $24 \mathrm{~h}$, then cut into specimens with $10 \times 10 \times 25 \mathrm{~mm}$ for the compressive strength test. Compressive strength was measured at a cross-head speed of $2.5 \mathrm{~mm} / \mathrm{min}$ by using a mechanical testing apparatus (SHIMADZU, Autograph AG$10 \mathrm{KNI}$ ). Porosities of hardened products were measured by the Archimedes method using $\mathrm{H}_{2} \mathrm{O}$ as a dipping liquid.

\section{RESULTS AND DISCUSSION}

FIGURE 1 shows XRD patterns of products quenched from $1500^{\circ} \mathrm{C}$ for $\mathrm{M}=\mathrm{Mg}$ and from $1400^{\circ} \mathrm{C}$ for the other M. All of products were the single $\alpha$-phase of TCP. Peak shifts due to the substitution of $\mathrm{M}$ ions for $\mathrm{Ca}$ ion in $\alpha-\mathrm{TCP}$ were not clear, however the following difference in hydration reactivity suggested the substitutions of $\mathrm{M}$.

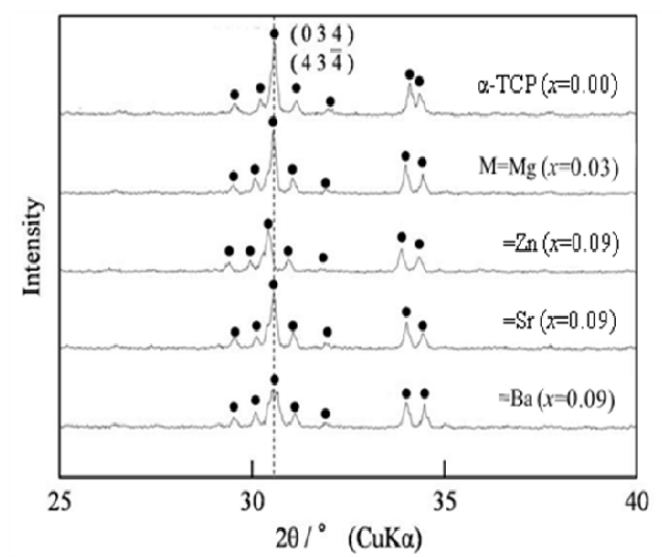

FIGURE 1 XRD patterns of $\alpha$-TCP and $\mathrm{Ca}_{3-\mathrm{x}} \mathrm{M}_{\mathrm{x}}\left(\mathrm{PO}_{4}\right)_{2}$.

$\bullet: \alpha$-phase of TCP

FIGURE 2 shows XRD patterns of products after the hydration runs for pure $\alpha$-TCP and $\left.\alpha-\mathrm{Ca}_{3-\mathrm{x}} \mathrm{M}_{\mathrm{x}}\left(\mathrm{PO}_{4}\right)_{2}\right)$ at $80^{\circ} \mathrm{C}$ for $1 \mathrm{~h}$. Pure $\alpha$-TCP and $\mathrm{Sr}$-substituted $\alpha$-TCP formed HAp with fairly amounts, however the case of $\mathrm{Ba}$ was a small, and the cases of $\mathrm{Mg}$ and $\mathrm{Zn}$ were non-changed. Although the resulting products with a lattice strain introduced by the substitutions for $\mathrm{Ca}$ were expected to be higher than pure $\alpha$-TCP in chemical reactivity, actually structural shrinkage or residual 
lattice strain seemed to chemically strengthen the $\alpha$-structure. The composition of the HAp must be nonstoichiometric, i.e., $\mathrm{Ca}_{10-\mathrm{x}}\left(\mathrm{HPO}_{4}\right)_{\mathrm{x}}$ $\left(\mathrm{PO}_{4}\right)_{6-\mathrm{x}}(\mathrm{OH})_{2-\mathrm{x}} \cdot n \mathrm{H}_{2} \mathrm{O} ; 0<x \leqq 1$.

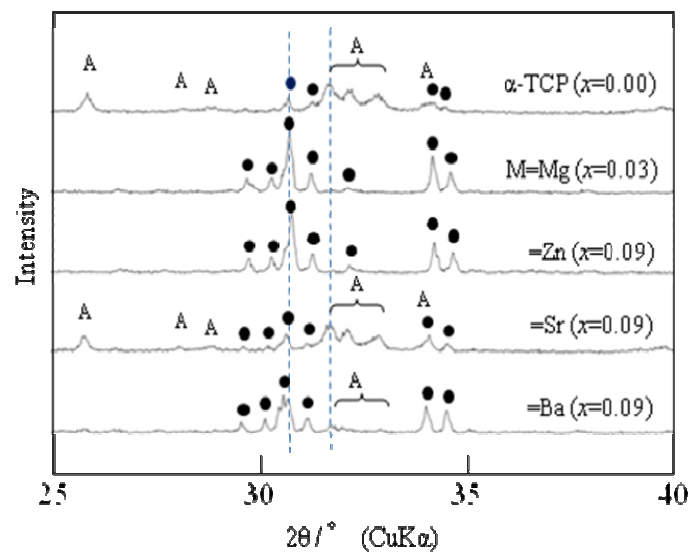

FIGURE 2 XRD patterns of $\alpha$-TCP and $\alpha-\mathrm{Ca}_{3-\mathrm{x}} \mathrm{M}_{\mathrm{x}}\left(\mathrm{PO}_{4}\right)_{2}$ after the hydration run at $80^{\circ} \mathrm{C}$ for $1 \mathrm{~h}$.

$\bullet: \alpha$-phase of TCP A:HAp

TABLE 1 summarized the above results on $\alpha-\mathrm{Ca}_{3-\mathrm{x}} \mathrm{M}_{\mathrm{x}}\left(\mathrm{PO}_{4}\right)_{2}$ compared to $\alpha$-TCP. FIGURE 3 shows SEM microstructures before and after the hydration runs of $\alpha$-phase TCP samples. In the case of $\alpha$-TCP, characteristic thin leaves of nonstoichiometic HAp were clearly observed.

TABLE 1 Characteristics of $\alpha-\mathrm{Ca}_{3-\mathrm{x}} \mathrm{M}_{\mathrm{x}}\left(\mathrm{PO}_{4}\right)_{2}$

\begin{tabular}{|c|c|c|c|c|c|c|}
\hline \multicolumn{2}{|l|}{ M } & $\mathrm{Mg}$ & Zn & $\mathrm{Ca}$ & $\mathrm{sr}$ & $\mathrm{Ba}$ \\
\hline \multicolumn{2}{|l|}{ Ion radius $1 \mathrm{mI}$} & $0.0 \div 2$ & $0.0^{75}$ & 0.100 & 0.116 & 0.136 \\
\hline \multicolumn{2}{|l|}{ T $x$} & 0.03 & 0.09 & 0.00 & 0.09 & 0.09 \\
\hline \multicolumn{2}{|l|}{ XRD phase* } & $a$ & a & a & a & $a$ \\
\hline \multirow{2}{*}{$\begin{array}{l}\text { Hydration } \\
\left(1 \mathrm{~g}^{\circ} 50 \mathrm{ml} \mathrm{H}_{2} \mathrm{O}\right) \\
\left.80^{\circ} \mathrm{C}-\mathrm{lh}\right)\end{array}$} & XRI plase* & $a$ & $a$ & $A \cdot a$ & $A>a$ & $a \gg \gg A$ \\
\hline & $\begin{array}{l}\text { Hardening } \\
\text { of sedimient }\end{array}$ & None & None & Yes & Yes & None \\
\hline
\end{tabular}

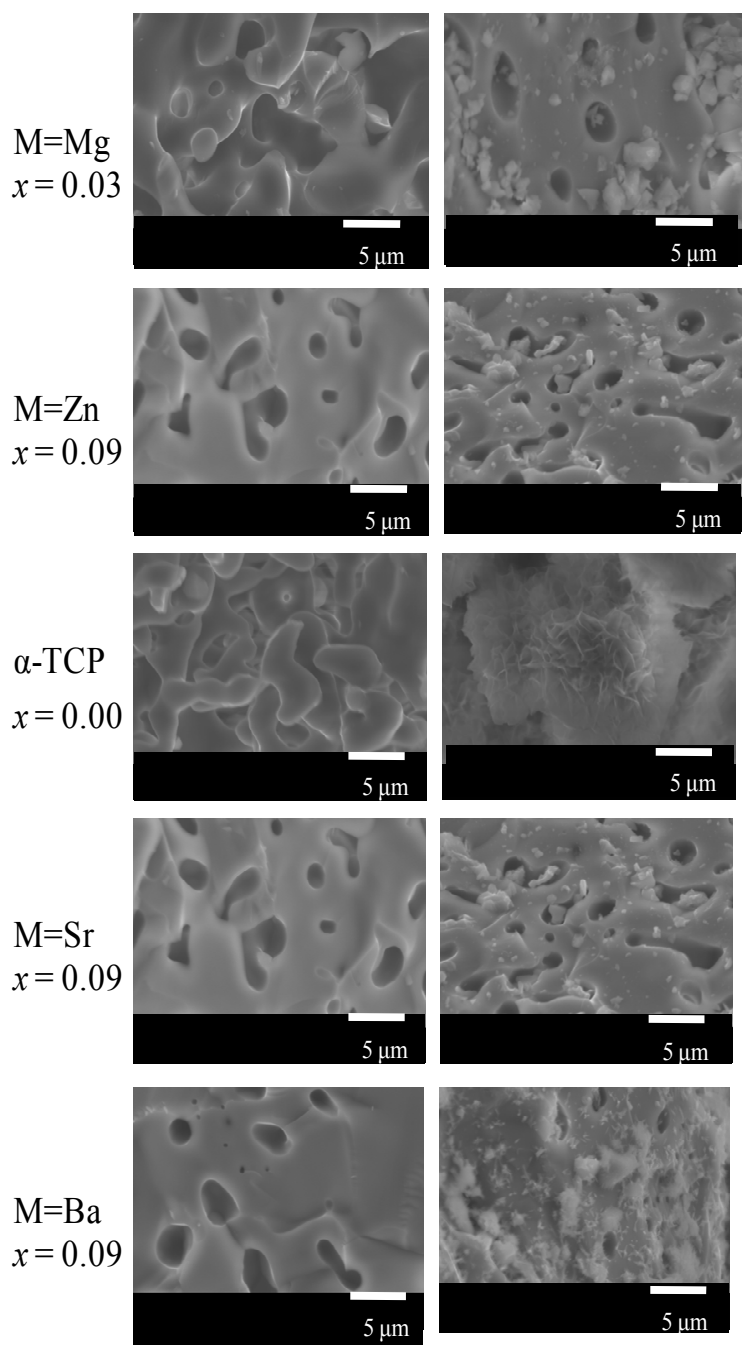

FIGURE 3 SEM photographs of $\alpha-\mathrm{Ca}_{3-\mathrm{x}}$ $\mathrm{M}_{\mathrm{x}}\left(\mathrm{PO}_{4}\right)_{2}$ before and after the hydration run at $80^{\circ} \mathrm{C}$ for $1 \mathrm{~h}$. Bar: $5 \mu \mathrm{m}$

Consequently, regardless of the ion size of the cations substituted for $\mathrm{Ca}$ in $\alpha$-TCP, the hydration reactivity of $\alpha$-TCP was decreased by the substitutions at impurity levels. Figure 4 shows a hardened specimen cut for compressive strength test. Figure 5 shows plots of compressive strength $v s$. porosity of thus obtained hardened bodies with literature data. It was considered that the plots for 


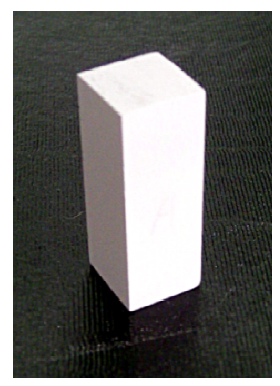

FIGURE 4 Specimen $(10 \times 10 \times 25 \mathrm{~mm})$ for compressive strength test.

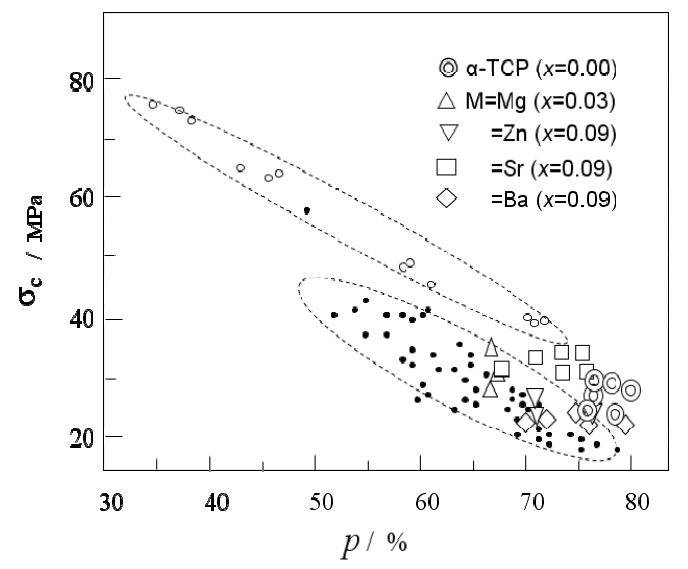

FIGURE 5 Plots of compressive strength $\left(\sigma_{\mathrm{c}}\right)$

$v s$. porosity $(p)$ of hardened bodies prepared at $80^{\circ} \mathrm{C}$ for $3 \mathrm{~h}$ from $\alpha-\mathrm{TCP}$ (○) and $\alpha-\mathrm{Ca}_{3-\mathrm{x}}$ $\mathrm{M}_{\mathrm{x}}\left(\mathrm{PO}_{4}\right)_{2}(\triangle, \nabla, \square, \diamond)$.

$\circ: \alpha-\mathrm{TCP}+\mathrm{CaHPO}{ }_{4} \cdot 2 \mathrm{H}_{2} \mathrm{O}+$ ascorbic acid cement slurry, centrifugal sediment hardened at $40^{\circ} \mathrm{C}-3 \mathrm{~h}^{5)}$

- : $\alpha$-TCP cement paste, hardened at $80^{\circ} \mathrm{C}-3 \mathrm{~h}^{6}{ }^{6}$ hardened bodies from paste ( this work ) were reasonable compared to those for centrifugal sediment $^{5)}$ and spontaneous sediment ${ }^{6)}$.

\section{CONCLUSIONS}

Divalent cation-substituted $\alpha$-tricalcium phosphates $\left(\alpha-\mathrm{Ca}_{3-\mathrm{x}} \mathrm{M}_{\mathrm{x}}\left(\mathrm{PO}_{4}\right)_{2}\right.$, where $\mathrm{M}=\mathrm{Mg}$, $\mathrm{Zn}, \mathrm{Sr}, \mathrm{Ba})$ were prepared and characterized by XRD, SEM, hydration reactivity and hardening strength. The hydration reactivity of pure $\alpha-$ TCP was decreased by the substitutions of either smaller or larger cations in size than $\mathrm{Ca}$. In other words, such divalent substitutions tended to stabilize the $\alpha$-TCP structure.

\section{REFERENCES}

1. H.Monma, T.Kanazawa, Yogyo-Kyokai-Shi, 86, 378(1978).

2. K.Yoshida, H.Hyuga, N.Kondo, H.Kita, M. Sasaki, M.Mitamura, K.Hashimoto, Y.Toda, J. Amer. Ceram. Soc., 89, 688(2006).

3. M.Motisuke, R.G.Carrodeguas, C.A.C. Zavaglia, Key Eng. Mater., 361-363, 199(2008).

4. M.W.Barnes, M.Klimkiewicz, P.W.Brown, J. Amer. Ceram. Soc., 75, 1423(1992).

5. H.Monma, Unpublished data.

6. H.Monma, S.Ueno, M.Tsutsumi, Gypsum \& Lime, No.156, 6(1978). 